\title{
Microbiological evaluation and shelf life of seed flour mixes used for infant feeding in rural northern Nigeria
}

\author{
Ibeanu, V. N. ${ }^{1 \star}$, Ene-Obong, H. N. ${ }^{2}$, Peter-Ogba, G. U. ${ }^{1}$ and Onyechi, U. A. ${ }^{1}$ \\ ${ }^{1}$ Department of Home Science, Nutrition and Dietetics, University of Nigeria, Nsukka. \\ ${ }^{2}$ Department of Biochemistry, College of Medicine, University of Calabar, Nigeria.
}

Received 20 March, 2015; Accepted 11 May, 2015

\begin{abstract}
This study investigates microbial load and shelf life of locally processed cereal-legume-oil seed flour mixes used for infant feeding in rural northern Nigeria. Free fatty acid (FFA), water activity $\left(a_{w}\right), p H$, total viable count (TVC) and presence of yeast, coliform bacteria and mold were the parameters determined. Hungry rice or Digitaria exilis, benne seed or Sesamum indicum and soybean or Glycine max seeds flours were produced using traditional processing methods, including washing, boiling, fermenting and roasting. The test samples were milled into flour that could pass through a $70 \mathrm{~mm}$ mesh sieve and blended on protein basis at 70:30 cereal-legume/oilseed ratios to produce $D_{70} S_{30}, D_{70} G_{30}$, $D_{70} S_{15} G_{15}, D_{70} S_{20} G_{10}$ and $D_{70} S_{10} G_{20}$ and stored at 30 to $32^{\circ} \mathrm{C}$ for 60 days. The parameters were determined at day 0 and intervals of 14, 28, 42 and 60 days. At the end of the storage period, all the parameters increased. FFA increased from $0.15-0.16 \%$ to $0.47-0.58 \%$; $a_{w}$ from $0.46-0.48$ to $0.72-0.80 ; \mathrm{pH}$ from 3.9 to $4.7-4.9$ and TVC from $<1.0 \times 10^{2}$ to $2.2 \times 10^{3}$ to $3.6 \times 10^{4} \mathrm{cfu} / \mathrm{g}$ for 0 and 60 days, respectively. The differences between the values of the parameters of the formulations were significant $(p<0.05)$ especially from day 14 . Yeast and coliform were not detected in all the samples but mold was detected from days 14 to 60 . The formulation $D_{70} S_{30}$ had best shelf life; however, the samples should be consumed within 14 days of production.
\end{abstract}

Key words: Seed flour, multi-mixes, children, microbial load, shelf life.

\section{INTRODUCTION}

Poor child-feeding practices and high rate of infection result in malnutrition and poor health of children (WHO, 2010; UNICEF, 2011). The period from birth to two years is a 'critical window' for the promotion of exclusive breastfeeding ( 0 to 6 months) and quality/adequate complementary feeding (6 to 24 months) to optimize growth, health, and development in children. In rural northern Nigeria, cereal, legume/oilseed based complementary porridges are local diets fed to children 6 to 24 months of age with continued breast feeding. Rural mothers combine different plant foods because they understand that dietary diversity (multi-mixes) is an

${ }^{*}$ Corresponding author. E-mail: vivienneibeanu@yahoo.co.uk. Tel: +234 8034831195.

Abbreviations: FFA, Free fatty acid; $\mathbf{a}_{\mathbf{w}}$, water activity; TVC, total viable count.

Author(s) agree that this article remains permanently open access under the terms of the Creative Commons Attribution License 4.0 International License 
effective approach to improve the quality of young children's plant-base diets especially without access to fortified food products (WHO/UNICEF, 2008). Combining cereals and legumes at the ratio of 70:30 have been shown to have nutrient potentials that complement one another in general (Fernandez et al., 2002) and have amino acid pattern that can compare with that of animal protein. Cereal and legume commonly blended for infant feeding are maize or millet and soybean. Other cereals and legumes/oilseed which are also cheap sources of plant protein but are under exploited and not commonly used in infant feeding include hungry rice (cereal) and benne seed (oilseed). They are under exploited in infant feeding general in Nigeria and in the south in particular; they are however used in rural north.

Hungry rice is one of the nutritious grains in the world (Thiam, 2008). It is particularly rich in many essential amino acids (National Academy of Science, 2006). Benne seed is an oil legume that is rich in micronutrients and phytochemicals (Bedigian, 2003). In the north of Nigeria where hungry rice and benne seed are combined in infant porridge, mothers frequently process these foods to produce complementary porridges. This is a gruesome task and in most cases facilities such as refrigerators to store the processed flour or paste are not available, they therefore store processed flour and pastes for less than seven days. The potentials of storing processed flour in standard household pantry beyond seven days could be exploited to reduce the work load and time for mothers and caregivers.

Shelf life is the length of time that a commodity such as food may be stored without becoming unfit for use or consumption. It is the recommended maximum time for which products can be stored during which the defined quality of a specified proportion of the goods remain acceptable under expected conditions of distribution, storage and display (Gyesley, 1991). A food product within its shelf life should be safe to eat, keep its appearance, colour, texture and flavour and meet any nutritional claims provided on the label (New Zealand Food Safety Authority, 2005). All foods spoil with time but the rate differs from food to food. Factors that affect food quality include microbial (bacteria, yeast and mold) growth, non-microbial spoilage (rancidity, browning and loss of nutrients) and product related spoilage such as water activity, $\mathrm{pH}$ and oxygen availability (Fontana, 2008; Sivasankar, 2010).

Free fatty acid in stored foods is used to measure rancidity. Enzymes inherent in foods hydrolyze fat in the food into free fatty acid and glycerol during storage (Morrison, 2006). Light, atmospheric oxygen and moisture also precipitate rancidity which changes the flavour and taste of food (Modi et al., 2004). Water activity of a food is the ratio between the vapour pressure of the food itself, when in a completely undisturbed balance with the surrounding air media and the vapour pressure of distilled water under identical condition (U.S.
Food and Drug Administration, 1984). A $a_{w}$ of 0.80 means that the vapour pressure is $80 \%$ of that of pure water. It is the amount of water in a food that is available for microbial use and it helps to predicts microbial growth (Fontana, 2001). Water activity predicts food stability with respect to microbial growth rate of deteriorative reaction and physical properties of foods (texture and shelf life) (Ukegbu and Anyika, 2012). High values support microbial growth, therefore, moist food spoils faster than dry food. A food or solution's $\mathrm{pH}$ is a measure of acidity or alkalinity using a numerical scale between 1 and 14 . Low $\mathrm{pH}$ value shows acidity and it limits the growth of many microorganisms and vice versa (International Commission on Microbiological Standards for Foods, 1996). The $\mathrm{pH}$ limit for growth of any microorganism is 0.60 (Fontana, 2008)

Microbial load of a food is determined by the levels of microorganisms (measured in colony forming units per gram) in the food during production, packaging, storage and other handing as well as the type of food in question. The end of shelf life can be based on the quantity of microorganism present (NZFSA, 2005). The objective of this study was to evaluate at intervals $(0,14,28,42$ and 60 days) microbial load and shelf life of cereallegume/oilseed multi-mixes used for infant feeding in rural northern Nigeria.

\section{MATERIALS AND METHODS}

Digitaria exilis, Sesamum indicum and Glycine max used for the study were purchased from a local market in Kaduna state in northern Nigeria and processed using traditional methods. $D$. exilis was washed, soaked in water $(1: 3$ ratio W/V), fermented for $48 \mathrm{~h}$ (with the water changed every $24 \mathrm{~h}$ ) and sundried. S. indicum seeds were washed, sundried and roasted at $80^{\circ} \mathrm{C}$ for $10 \mathrm{~min}$. Glycine max seeds were also washed and boiled at $100^{\circ} \mathrm{C}$ for 60 min dehulled manually, soaked in water (1:3 ratio W/V), fermented for $24 \mathrm{~h}$ (with the water changed every $24 \mathrm{~h}$ ) and sundried. The dried Glycine max seeds were roasted at $80^{\circ} \mathrm{C}$ for $10 \mathrm{~min}$. The residual moisture after the processing of the food items was approximately $3 \%$. All the processed seeds were milled (to pass through a $70 \mathrm{~mm}$ mesh sieve) separately into flour and analyzed for crude nitrogen $(\mathrm{N})$ before being blended on the basis of their crude nitrogen $(\mathrm{N})$ concentration. Each blend derived $70 \%$ of its dietary nitrogen from cereal (hungry rice) and 30\% from legume (soybean) and or oilseed (benne seed) and furnished $20 \mathrm{~g}$ of protein per day. Five multi-mix formulations were $D$. exilis $s_{70}$ and $S$. indicum ${ }_{30}$ $\left(D_{70} S_{30}\right) ; D$. exilis 70 and G. $\max _{30}\left(D_{70} G_{30}\right)$; D. exilis 5 . indicum $m_{15}$ G. $\max _{15}\left(\mathrm{D}_{70} \mathrm{~S}_{15} \mathrm{G}_{15}\right)$; D. exilis $5_{70}, S$. indicum 20 and $G$. $\max _{10}$ $\left(\mathrm{D}_{70} \mathrm{~S}_{20} \mathrm{G}_{10}\right)$ and $D$. exilis 70 , G. $\max _{20}$ and $S$. indicum ${ }_{10}\left(\mathrm{D}_{70} \mathrm{G}_{20} \mathrm{~S}_{10}\right)$. $10 \mathrm{~g}$ of each mix was packaged in self-sealed polyethylene food bags and stored in a standard household pantry at 30 to $32^{\circ} \mathrm{C}$ for 60 days.

Free fatty acid (FFA), water activity $\left(\mathrm{a}_{\mathrm{w}}\right), \mathrm{pH}$ and microbiological load of each mix were analyzed in triplicate using standard procedures at days $0,14,28,42$ and 60 . Free fatty acid was determined by the method of Association of Official Analytical Chemists (AOAC) (2005). The $\mathrm{pH}$ was determined using standard electrode $\mathrm{pH}$ meter as described by AOAC (1990). Water activity value analyzer model 5803 , Germany was used to assess the water activity of the samples. The microbiological load was determined by serial dilution of each sample in ten-fold with sterile $0.1 \%$ media by 
Table 1. Percentage free fatty acids of seed flour mixes made from Digitaria exilis Sesamum indicum and Glycine max seed flours.

\begin{tabular}{lccccc}
\hline Sample code & 0 day & 14 days & 28 days & 42 days & 60 days \\
\hline $\mathrm{D}_{70} \mathrm{~S}_{30}$ & $0.15 \pm 0.01^{\mathrm{b}}$ & $0.26 \pm 0.01^{\mathrm{b}}$ & $0.27 \pm 0.01^{\mathrm{c}}$ & $0.37 \pm 0.01^{\mathrm{b}}$ & $0.47 \pm 0.02^{\mathrm{c}}$ \\
$\mathrm{D}_{70} \mathrm{G}_{30}$ & $0.15 \pm 0.01^{\mathrm{b}}$ & $0.36 \pm 0.01^{\mathrm{a}}$ & $0.46 \pm 0.01^{\mathrm{a}}$ & $0.47 \pm 0.02^{\mathrm{a}}$ & $0.58 \pm 0.04^{\mathrm{a}}$ \\
$\mathrm{D}_{70} \mathrm{~S}_{15} \mathrm{G}_{15}$ & $0.15 \pm 0.02^{\mathrm{b}}$ & $0.36 \pm 0.02^{\mathrm{a}}$ & $0.46 \pm 0.02^{\mathrm{a}}$ & $0.47 \pm 0.01^{\mathrm{a}}$ & $0.58 \pm 0.05^{\mathrm{a}}$ \\
$\mathrm{D}_{70} \mathrm{~S}_{20} \mathrm{G}_{10}$ & $0.15 \pm 0.01^{\mathrm{b}}$ & $0.25 \pm 0.02^{\mathrm{c}}$ & $0.36 \pm 0.01^{\mathrm{b}}$ & $0.47 \pm 0.03^{\mathrm{a}}$ & $0.57 \pm 0.01^{\mathrm{b}}$ \\
$\mathrm{D}_{70} \mathrm{~S}_{10} \mathrm{G}_{20}$ & $0.16 \pm 0.01^{\mathrm{a}}$ & $0.36 \pm 0.01^{\mathrm{a}}$ & $0.46 \pm 0.02^{\mathrm{a}}$ & $0.47 \pm 0.05^{\mathrm{a}}$ & $0.58 \pm 0.01^{\mathrm{a}}$ \\
\hline
\end{tabular}

Means \pm SD of 3 determinations; means with different superscript on a column are significantly different. $\mathrm{D}_{70} \mathrm{~S}_{30}=$ Digitaria exilis $S_{70} /$ Sesamum indicum $\mathrm{m}_{30} ; \mathrm{D}_{70} \mathrm{G}_{30}=$ Digitaria exilis ${ }_{70} /$ Glycine $\max _{30} ; \mathrm{D}_{70} \mathrm{~S}_{15} \mathrm{G}_{15}=$ Digitaria exilis $70 /$ Sesamum indicum $15 /$ Glycine $\max _{15}$; $\mathrm{D}_{70} \mathrm{~S}_{20} \mathrm{G}_{10}=$ Digitaria exilis 70 Sesamum indicum I0 $_{\text {Glycine }} \max _{10} ; \mathrm{D}_{70} \mathrm{~S}_{10} \mathrm{G}_{20}=$ Digitaria exilis ${ }_{70} /$ Sesamum indicum 10 / Glycine max $_{20}$.

Table 2. Water activity $\left(\mathrm{a}_{\mathrm{w}}\right)$ of seed flour mixes made from Digitaria exilis, Sesamum indicum and Glycine max seed flours.

\begin{tabular}{lccccc}
\hline Sample code & $\mathbf{0}$ day & $\mathbf{1 4}$ days & 28 days & 42 days & 60 days \\
\hline $\mathrm{D}_{70} \mathrm{~S}_{30}$ & $0.48 \pm 0.01^{\mathrm{a}}$ & $0.53 \pm 0.01^{\mathrm{e}}$ & $0.55 \pm 0.01^{\mathrm{d}}$ & $0.61 \pm 0.01^{\mathrm{c}}$ & $0.72 \pm 0.01^{\mathrm{e}}$ \\
$\mathrm{D}_{70} \mathrm{G}_{30}$ & $0.47 \pm 0.00^{\mathrm{a}}$ & $0.55 \pm 0.01^{\mathrm{c}}$ & $0.60 \pm 0.01^{\mathrm{a}}$ & $0.61 \pm 0.01^{\mathrm{c}}$ & $0.80 \pm 0.01^{\mathrm{a}}$ \\
$\mathrm{D}_{70} \mathrm{~S}_{15} \mathrm{G}_{15}$ & $0.47 \pm 0.01^{\mathrm{a}}$ & $0.58 \pm 0.01^{\mathrm{a}}$ & $0.58 \pm 0.01^{\mathrm{b}}$ & $0.60 \pm 0.03^{\mathrm{d}}$ & $0.78 \pm 0.02^{\mathrm{b}}$ \\
$\mathrm{D}_{70} \mathrm{~S}_{20} \mathrm{G}_{10}$ & $0.48 \pm 0.01^{\mathrm{a}}$ & $0.54 \pm 0.02^{\mathrm{d}}$ & $0.57 \pm 0.02^{\mathrm{c}}$ & $0.65 \pm 0.01^{\mathrm{a}}$ & $0.75 \pm 0.01^{\mathrm{d}}$ \\
$\mathrm{D}_{70} \mathrm{~S}_{10} \mathrm{G}_{20}$ & $0.46 \pm 0.01^{\mathrm{b}}$ & $0.57 \pm 0.01^{\mathrm{b}}$ & $0.58 \pm 0.01^{\mathrm{b}}$ & $0.62 \pm 0.01^{\mathrm{b}}$ & $0.77 \pm 0.01^{\mathrm{c}}$ \\
\hline
\end{tabular}

Means \pm SD of 3 determinations; means with different superscript on a column are significantly different. $\mathrm{D}_{70} \mathrm{~S}_{30}=$ Digitaria exilis $\mathrm{s}_{70} /$ Sesamum indicum $\mathrm{H}_{30} ; \mathrm{D}_{70} \mathrm{G}_{30}=$ Digitaria exilis ${ }_{70} /$ Glycine $\max _{30} ; \mathrm{D}_{70} \mathrm{~S}_{15} \mathrm{G}_{15}=$ Digitaria exilis ${ }_{70} /$ Sesamum indicum 15 /Glycine $\max _{15}$; $\mathrm{D}_{70} \mathrm{~S}_{20} \mathrm{G}_{10}=$ Digitaria exilis $70 /$ Sesamum indicum $20 / G$ lycine $\max _{10} ; \mathrm{D}_{70} \mathrm{~S}_{10} \mathrm{G}_{20}=$ Digitaria exilis $70 /$ Sesamum indicum 10 / Glycine max $_{20}$.

pour plate technique as described by AOAC (1990). Coliform count was determined using nutrient agar with $24 \mathrm{~h}$ incubation at $37^{\circ} \mathrm{C}$; sabour and dextrose agar was used for yeast $/$ mold with $48 \mathrm{~h}$ incubation at room temperature while for TVC it was $24 \mathrm{~h}$ incubation at $37^{\circ} \mathrm{C}$. One way analysis of variance (ANOVA) and Duncan's multiple range tests were used to separate/compare means obtained between groups. Differences were considered significant at $p<0.05$.

\section{RESULTS}

Table 1 presents the percentage of FFA in the seed flour mixes. The FFA values of all the blends increased with storage $(p<0.05)$. At day $0, D_{70} S_{10} G_{20}$ had the highest FFA $(0.16 \%)$ while the $D_{70} G_{30}, D_{70} S_{30}, D_{70} S_{15} G_{15}$, and $D_{70} S_{10} G_{20}$ had $0.15 \%$. At day 60 , the $D_{70} S_{30}$ had the least FFA value $(0.47 \%)$ while $D_{70} G_{30}, D_{70} S_{15} G_{15}$ and $D_{70} S_{10}$ had the highest value $(0.58 \%)$. There were differences $(p<0.05)$ among the FFA values of the samples especially on days 14 and 28 . Table 2 shows water activity $\left(a_{w}\right)$ values of the seed flour mixes at different intervals. The values ranged from 0.46 in $D_{70} S_{10} G_{20}$ to 0.48 in $D_{70} S_{30}$ and $D_{70} S_{20} G_{10}$ at day 0 . At day $14, D_{70} S_{15} G_{15}$ had the highest water activity of 0.58 , followed by $D_{70} S_{10} G_{20}(0.57$ $\left.a_{w}\right), D_{70} G_{30}\left(0.55 a_{w}\right)$ and $D_{70} S_{20} G_{10}\left(0.54 a_{w}\right) . D_{70} S_{30}$ had the least value $\left(0.53 \mathrm{a}_{\mathrm{w}}\right)$. At day 28 of storage, $\mathrm{D}_{70} \mathrm{G}_{30}$ had the highest value $\left(0.60 \mathrm{a}_{\mathrm{w}}\right)$ and the $\mathrm{D}_{70} \mathrm{~S}_{30}$ had the least value $\left(0.55 \mathrm{a}_{\mathrm{w}}\right)$. The water activity of all the samples were similar at days 28 and 42 , but showed significant differences $(p<0.05)$ between days 0 and 60 . There was a progressive increase in the $\mathrm{pH}$ values of the samples with storage (Table 3). At day 0 , all the samples had the same $\mathrm{pH}$ value (3.9). The $\mathrm{pH}$ values at day 14 ranged from 4.0 in $D_{70} S_{10} G_{20}$ to 4.2 in $D_{70} S_{15} G_{15}$ while at day 42 , it ranged from 4.5 in $D_{70} S_{30}$ and $D_{70} S_{15} G_{15}$ to 4.8 in $D_{70} G_{30}$ and $D_{70} S_{10} G_{20}$ and 4.9 in $D_{70} G_{30}$. The decrease in acidity was significant $(p<0.05)$ from day 0 to day 60 . However, there were no significant differences $(P>0.05)$ in the $\mathrm{pH}$ values of the samples at a particular interval except in days 28,42 and 60 . At day 0 , all the samples had the same TVC value of $<1.0 \times 10^{2} \mathrm{cfu} / \mathrm{g}$ except for $D_{70} G_{30}$ (Table 4). At day $14, D_{70} S_{30}$ and $D_{70} S_{20} G_{10}$ had the least $\left(1.0 \times 10^{2}\right)$ TVC value and $D_{70} G_{30}$ had the highest $\left(1.4 \times 10^{2}\right.$ $\mathrm{cfu} / \mathrm{g})$. At the end of 60 days of storage, $D_{70} G_{30}$ had the highest $\left(3.6 \times 10^{4} \mathrm{cfu} / \mathrm{g}\right)$ and $\mathrm{D}_{70} \mathrm{~S}_{30}$ the least $\left(2.2 \times 10^{3} \mathrm{cfu} / \mathrm{g}\right)$ TVC value. Only mold $(<100 \mathrm{cfu} / \mathrm{g})$ was detected from the 14 days. At day 60 , the $D_{70} G_{30}$ had the highest mold value $\left(2.4 \times 10^{4} \mathrm{cfu} / \mathrm{g}\right)$, followed by $\mathrm{D}_{70} \mathrm{~S}_{15} \mathrm{G}_{15}\left(2.6 \times 10^{3}\right.$ $\mathrm{cfu} / \mathrm{g}), \quad D_{70} S_{10} G_{20} \quad\left(1.7 \times 10^{3} \mathrm{cfu} / \mathrm{g}\right), D_{70} S_{20} G_{10} \quad\left(2.7 \times 10^{2}\right.$ 
Table 3. $\mathrm{pH}$ of seed flour mixes made from Digitaria exilis, Sesamum indicum and Glycine max seed flours measured at intervals.

\begin{tabular}{lccccc}
\hline Sample code & 0 day & 14 days & 28 days & 42 days & 60 days \\
\hline $\mathrm{D}_{70} \mathrm{~S}_{30}$ & $3.9 \pm 0.01^{\mathrm{a}}$ & $4.1 \pm 0.00^{\mathrm{a}}$ & $4.4 \pm 0.03^{\mathrm{b}}$ & $4.5 \pm 0.00^{\mathrm{c}}$ & $4.7 \pm 0.03^{\mathrm{c}}$ \\
$\mathrm{D}_{70} \mathrm{G}_{30}$ & $3.9 \pm 0.02^{\mathrm{a}}$ & $4.1 \pm 0.01^{\mathrm{a}}$ & $4.5 \pm 0.05^{\mathrm{a}}$ & $4.8 \pm 0.01^{\mathrm{a}}$ & $4.9 \pm 0.04^{\mathrm{a}}$ \\
$\mathrm{D}_{70} \mathrm{~S}_{15} \mathrm{G}_{15}$ & $3.9 \pm 0.01^{\mathrm{a}}$ & $4.2 \pm 0.00^{\mathrm{a}}$ & $4.4 \pm 0.01^{\mathrm{b}}$ & $4.5 \pm 0.00^{\mathrm{c}}$ & $4.7 \pm 0.02^{\mathrm{c}}$ \\
$\mathrm{D}_{70} \mathrm{~S}_{20} \mathrm{G}_{10}$ & $3.9 \pm 0.02^{\mathrm{a}}$ & $4.1 \pm 0.04^{\mathrm{a}}$ & $4.4 \pm 0.02^{\mathrm{b}}$ & $4.7 \pm 0.02^{\mathrm{b}}$ & $4.8 \pm 0.01^{\mathrm{b}}$ \\
$\mathrm{D}_{70} \mathrm{~S}_{10} \mathrm{G}_{20}$ & $3.9 \pm 0.03^{\mathrm{a}}$ & $4.0 \pm 0.00^{\mathrm{a}}$ & $4.3 \pm 0.02^{\mathrm{c}}$ & $4.8 \pm 0.03^{\mathrm{a}}$ & $4.9 \pm 0.03^{\mathrm{a}}$ \\
\hline
\end{tabular}

Means \pm SD of 3 determinations; means with different superscript on a column are significantly different. $\mathrm{D}_{70} \mathrm{~S}_{30}=$ Digitaria exilis ${ }_{70} /$ Sesamum indicum ${ }_{30} ; \mathrm{D}_{70} \mathrm{G}_{30}=$ Digitaria exilis $/$ Glycine $\max _{30} ; \mathrm{D}_{70} \mathrm{~S}_{15} \mathrm{G}_{15}=$ Digitaria exilis ${ }_{70} /$ Sesamum indicum ${ }_{15} /$ Glycine $\max _{15}$; $\mathrm{D}_{70} \mathrm{~S}_{20} \mathrm{G}_{10}=$ Digitaria exilis ${ }_{70} /$ Sesamum indicum ${ }_{20} /$ Glycine $\max _{10} ; \mathrm{D}_{70} \mathrm{~S}_{10} \mathrm{G}_{20}=$ Digitaria exilis ${ }_{70} /$ Sesamum indicum 10 / Glycine $\max _{20}$.

Table 4. Total viable count (TVC), mold, yeast and coliform count (cfu/g) of seed flour mixes made from Digitaria exilis, Sesamum indicum and Glycine max seed flours.

\begin{tabular}{|c|c|c|c|c|c|c|}
\hline Parameter & Intervals (days) & $\mathrm{D}_{70} \mathrm{~S}_{30}$ & $D_{70} G_{30}$ & $D_{70} S_{15} G_{15}$ & $\mathrm{D}_{70} \mathrm{~S}_{20} \mathrm{G}_{10}$ & $D_{70} S_{10} G_{20}$ \\
\hline \multirow{5}{*}{ TVC } & 0 & $<1.0 \times 10^{2 a}$ & $1.0 \times 10^{2 a}$ & $<1.0 \times 10^{2 a}$ & $<1.0 \times 10^{2 a}$ & $<1.0 \times 10^{2 a}$ \\
\hline & 14 & $1.0 \times 10^{2 d}$ & $1.4 \times 10^{\mathrm{a}}$ & $1.2 \times 10^{2 c}$ & $1.0 \times 10^{2 d}$ & $1.3 \times 10^{2 b}$ \\
\hline & 28 & $2.2 \times 10^{2 \mathrm{c}}$ & $2.0 \times 10^{2 \mathrm{c}}$ & $1.5 \times 10^{2 \mathrm{c}}$ & $2.0 \times 10^{2 c}$ & $1.8 \times 10^{2 c}$ \\
\hline & 42 & $2.0 \times 10^{3 c}$ & $2.2 \times 10^{3 b}$ & $1.8 \times 10^{3 d}$ & $2.3 \times 10^{3 a}$ & $2.0 \times 10^{3 c}$ \\
\hline & 60 & $2.2 \times 10^{3 d}$ & $3.6 \times 10^{4 a}$ & $2.4 \times 10^{3 c}$ & $2.6 \times 10^{3 \mathrm{~b}}$ & $2.1 \times 10^{4 e}$ \\
\hline \multirow{5}{*}{ Mold } & 0 & N.D & N.D & N.D & N.D & N.D \\
\hline & 14 & $6.0 \times 10^{1 \mathrm{c}}$ & $5.0 \times 10 a^{d}$ & $8.0 \times 10 a$ & $6.0 \times 10^{1 \mathrm{c}}$ & $7.0 \times 10^{1 b}$ \\
\hline & 28 & $1.0 \times 10^{2 \mathrm{c}}$ & $1.1 \times 10^{2 b}$ & $1.3 \times 10^{2 a}$ & $1.0 \times 10^{2 \mathrm{c}}$ & $1.1 \times 10^{2 b}$ \\
\hline & 42 & $2.0 \times 10^{2 \mathrm{c}}$ & $2.2 \times 10^{2 \mathrm{c}}$ & $2.3 \times 10^{2 b}$ & $2.0 \times 10^{2 c}$ & $2.5 \times 10^{2 a}$ \\
\hline & 60 & $2.5 \times 10^{2 \mathrm{e}}$ & $2.4 \times 10^{4 a}$ & $2.6 \times 10^{3 b}$ & $2.7 \times 10^{2 d}$ & $1.7 \times 10^{3 \mathrm{c}}$ \\
\hline Yeast & $0-60$ & N.D & N.D & N.D & N.D & N.D \\
\hline Coliform & $0-60$ & N.D & N.D & N.D & N.D & N.D \\
\hline
\end{tabular}

Means \pm SD of 3 determinations; means with different superscript on a column are significantly different. $\mathrm{D}_{70} \mathrm{~S}_{30}=$ Digitaria exilis $70 /$ Sesamum indicum $m_{30} ; \mathrm{D}_{70} \mathrm{G}_{30}=$ Digitaria exilis $5_{70} /$ Glycine max $_{30} ; \mathrm{D}_{70} \mathrm{~S}_{15} \mathrm{G}_{15}=$ Digitaria exilis $70 /$ Sesamum indicum $15 /$ Glycine $\max _{15} ; \mathrm{D}_{70} \mathrm{~S}_{20} \mathrm{G}_{10}=$ Digitaria exilis $S_{70} /$ Sesamum indicum $20 /$ Glycine $\max _{10}$; $D_{70} S_{10} G_{20}=$ Digitaria exilis $70 /$ Sesamum indicum $10 /$ Glycine $\max _{20}$. ND = Not detected.

$\mathrm{cfu} / \mathrm{g}) . \mathrm{D}_{70} \mathrm{~S}_{30}$ had the least value $\left(2.5 \times 10^{2} \mathrm{cfu} / \mathrm{g}\right)$. The differences were significant $(p<0.05)$ across the different intervals. The same trend was observed in mold. Yeast and coliform were not detected in all the samples throughout the storage period.

\section{DISCUSSION}

At day 0 , all the samples had FFA value of $0.15 \%$ except the $D_{70} S_{10} G_{20}$ which had $0.16 \%$. These values gradually increased during the 60 days of storage probably due to hydrolysis of fat. This is in agreement with the report of Sewald and DeVries (2003) that hydrolysis of glycerides could account for increased values of free fatty acid in stored flours. The low FFA values observed in the $D_{70} S_{30}$ after 60 days of storage relative to the other mixes could be attributed to absence of benne seed in the blend. This implied that $D_{70} S_{30}$ would have a longer keeping quality because long shelf life is associated with low FFA of a food/product (Food Chain, 2001). However, the values of all the samples were below the range $(0.5$ to $1.5 \%)$ that Onwuka (2005) reported when rancidity began to be noticed in most oils and oil rich foods. Also, antioxidant (sesamol and sesamolina) content of benne seed could have contributed to the long shelf life of the mixes (Bedigian, 2003; Ologunde, 2011). The water activity $\left(a_{w}\right)$ of each blend increased with storage. This could be due to concomitant increase in moisture content and as a function of time and temperature (Rong, 2007). The low water activity of the mixes on day 0 relative to the subsequent days could be associated with fermentation 
of the staples. This is in agreement with an earlier report by Mba-Anyadioha (2008) that fermentation increased acidity which reduced the water activity and moisture level in which the fermenting organisms thrive successfully. In addition, sun drying and roasting might have contributed to the reduced values obtained. The water activity values of all the mixes were below the value (0.91) in which most food spoilage bacteria do not grow (Sivasankar, 2010). Spoilage bacteria and mold require $0.91 \mathrm{a}_{\mathrm{w}}$ and $0.70 \mathrm{a}_{\mathrm{w}}$, respectively for growth (Sivasankar, 2010). The lower limit for growth of mycotoxigenic mold is about $0.78 \mathrm{a}_{\mathrm{w}}$. Also, yeast was not detected in all the blends throughout the storage period because $a_{w}$ values were below the value $(0.88)$ that supports yeast growth (Fontana, 2008).

The $\mathrm{pH}$ of all the samples was 3.9 on production. This indicated acidity, which might be due to production of weak acid during fermentation of the grains (MbaAnyadioha 2008). The $\mathrm{pH}$ of a food encourages or discourages growth and survival of microflora in that food (Fontana, 2008). Low pH value (acidity) did not favour the growth of pathogens such as Enterobacteriaceae and Aspergillus which are implicated in infantile diarrhoeal diseases (Rong, 2007). The optimum pH for growth of Enterobacteriaceae is in the range of 6.0 to 8.0 (ICMSF, 1996). As the storage progressed, the $\mathrm{pH}$ of the samples gradually increased to 4.9 in $D_{70} S_{15} G_{15}$ and $D_{70} S_{15} G_{15}$. Such increase according to Rong (2007) could be attributed to chemical changes. The final $\mathrm{pH}$ value (4.9) of the samples was below the value that encourages microbial growth. The low $\mathrm{pH}$ of samples at the end of storage period meant that microbial activities in food products were reduced and that helped to extend the shelf-life of the samples.

Yeasts and coliforms were not detected in the mixes throughout the storage period of 60 days probably because of the acidification of the medium by lactic acid fermenters (Mba-Anyadioha, 2008) and storage temperature. The low microbial load of the complementary mixes was due to low water activity and low pH caused by fermentation of the grains (Mensah et al., 1990). Fermentation induced an anti-microbial environment that reduced the risk of microbial contamination as observed by Ayoya et al. (2010) in home-made complementary foods. The low microbial load could also be due to roasting of the food samples. Roasting reduces micro-organisms and enzyme activity and destroys insects to improve keeping qualities (FAO/WHO, 2012). However, the total viable counts of formulated complementary mixes were within the acceptable limits of $10^{7} \mathrm{cfu} / \mathrm{g}$ (ICMSF, 1996) for flours. The detection of mold at day 14 could be attributed to post production contamination from the environment (including the storage material), temperature, increased water activity and $\mathrm{pH}$. The temperature and $\mathrm{pH}$ ranges that favour mold growth are 10 to $35^{\circ} \mathrm{C}$ and 2 to 9 , respectively. However, the mold counts of all the samples were within ICMSF
(1996) specifications $\left(10^{5} \mathrm{cfu} / \mathrm{g}\right)$ for flours. Microbial proliferations in foods need certain conditions - namely available water (water activity), proper $\mathrm{pH}$, right temperature and nutrients and time. By controlling these conditions one can prevent microbial growth and extend the shelf life of a food. At the end of the storage period, the samples had FFA values below the range that rancidity was observed in a previous study. Also, $a_{w}$ values were below that which allows for proliferation of microorganisms. The $\mathrm{pH}$ was slightly above the value (4.6) at which a product is said to be acidic however, it was below the level which encourages microbial proliferation. Yeasts and coliforms were not detected in the mixes throughout the storage period of 60 days. The presence of mold from day 14 meant that the mixes should be consumed within 14 days of production. Sanitation is a factor in the control of microbial growth. The flours should be prepared under hygienic conditions and stored in air-tight container and in clean and dry pantry that is not dark to discourage growth of mold. Also, porridge made from the flour should be well cooked to further ensure safety.

\section{Conflict of interests}

The authors did not declare any conflict of interest.

\section{REFERENCES}

Association of Official Analytical Chemists (AOAC) (1990). Official methods of analysis $15^{\text {th }}$ ed. Washington, D.C

Association of Official Analytical Chemists (AOAC) (2005). Official methods of analysis $18^{\text {th }}$ ed. Washington, D.C

Ayoya NA, Kodio J, Iknane AA, Sodjinou R (2010). Nutritional value of locally produced foods and for age- appropriate complementary foods for children under 2 years of age in Mali. Food Nutr. Bull. 31:391399.

Bedigian D (2003). Evolution of sesame revisited: domestication, diversity and prospects. Genet. Resour. Crop Evol. 50:779-787.

FAO/WHO Food Standards Programme (2012). Codex committee on nutrition and foods for special dietary uses: Report of the 33rd Physical Working Group on Proposed Draft of the Guidelines on Formulated Supplementary Foods for Older Infants and Young Children. Ghana and United States, WHO.

Fernandez DE, Vanderjagt DJ, Williams M, Huarg YS, Chuang L Millson M, Andrew R, Pastuszyn A, Glew RH (2002). Fatty acids, amino acids and trace mineral analyses of five weaning foods from Jos, Nigeria. Plant Foods Hum. Nutr. 57:257-274.

Fontana AJ. (2008). Water activity and $\mathrm{pH}$ measurement for Food Safety, Retail Food Systems Research Conference IFT Foodservice Division, Decagon Devices, Inc.

Food Chain (2001). Cashew processing and marketing. Int. J. Small Scale Process. 28:34

Fotana AJ (2001). Current protocols in food analytical chemistry, Washington, John Wiley \& sons Inc A221-A2210.

Gyesley SW (1991). Total systems approach to predict shelf life of packaged foods. American s Standard Technical Publications 111 EB

International Commission on Microbiological Standards for Foods [ICMSF] (1996). Microorganisms in foods 5. Characteristics of microbial pathogens, Gaithersburg, Aspen Publishers Inc.

Mba-Anyadioha AE (2008). Production and evaluation of microbiological 
safe complementary food based on fermented maize and soybeans flours. Nig. J. Nutr. Sci. 30 (1):26-31.

Mensah PA, Tomkins AM, Drasa BS, Harrison TJ (1990). Fermentation of cereals for reduction of bacterial contamination of weaning foods in Ghana. Lancet 334:140-143.

Modi VK, Mahendrakar NS, Narasimha Rao D, Sachindra NM (2004). Quality of buffalo meat burger containing legume flours as binders. Meat Sci. 66:143-149.

Morrison WR (2006). The stability of wheat starch lipids in untreated and chlorine-treated cake flours. J. Sci. Food Agric. 29 (4):365-371.

National Academy of Science (2006). Lost crops of Africa: grain. Retrieve January 12, 20011 from http:/www.answer.com

Ologunde MO, Omosebi MO, Ariyo O, Olunlade BA, Abolaji RA (2011). Preliminary nutritional evaluation of cashew nuts from different locations in Nigeria. Cont. J. Food Sci. Technol. 5:2

Onwuka Gl (2005). Food analysis and instrumentation: theory and practice. Lagos, Naphali Prints, 160

Rong MY (2007). The Cause of Bitter Flavour Development in Toasted Rolled Oats (Avena sativa L.). Thesis submitted in partial fulfilment of the degree of Master of Applied Science Auckland University of Technology Auckland, New Zealand, 94.

Sewald M, DeVries J (2003). Food product shelf life. Medallion Laboratories Analytical Progress.
Sivasankar B (2010). Food processing and preservation. New Delhi, PHI Learning Private Limited. pp. 12-19.

Thiam P (2008). Yolele: recipes from the heart of Senegal. Retrieved January 10, 2010 from splendidtable.pulicrado.org/recipe.

U.S Food and Drug Administration (1984). Water activity $\left(a_{w}\right)$ in foods. Department of Health and Welfare Public Health services ORA/ORO/DE10/IB

Ukegbu PO, Anyika JU (2012). Chemical analysis and nutrient adequacy of maize gruel (pap) supplemented with other food sources in Ngor-Okpala Iga, Imo state, Nigeria. J. Biol. Agric. Healthcare 2 (6):13-21.

UNICEF (2011). Overview of Nutritional Status of Nigerians. Presentation at a seminar on High Quality Protein: The Missing Link in Development. March $8^{\text {th }}$ 2011, Protea Hotel Ikeja, Lagos.

WHO (2010). Infant and young child feeding. Retrieved October 23, $2011 \mathrm{from} \mathrm{http://www.who.int/mediacentre/factsheets/fs342.}$

WHO/UNICEF (2008). Strengthening action to improve feeding of infants and young children from 6-23 months of age in nutrition and child health programmes. Geneva, WHO, 74. 